\title{
Analisis Tingkat Literasi Keuangan pada Pelaku Usaha Mikro Kecil dan Menengah Kerajinan Perak di Kotagede Yogyakarta
}

\author{
Joko Prihatin ${ }^{1}$ dan Ahmad Maruf ${ }^{1}$
}

\begin{abstract}
Abstrak: Penelitian ini dilakukan untuk menganalisis tingkat literasi keuangan pada pelaku UMKM (Usaha Mikro Kecil dan Menengah) kerajinan perak di Kotagede Yogyakarta. Variabel-variabel bebas (independen) yang digunakan dalam penelitian ini adalah: jenis kelamin, usia, tingkat pendidikan terakhir, lama usaha, dan omzet penjualan per-bulan. Hasil penelitian menunjukkan rata-rata tingkat literasi keuangan pelaku UMKM kerajinan perak di Kotagede Yogyakarta, berada pada kategori sedang. Variabel yang mempengaruhinya adalah: usia, tingkat pendidikan terakhir, lama usaha, dan omzet penjualan per-bulan berpengaruh signifikan terhadap tingkat literasi keuangan pelaku UMKM kerajinan perak di Kotagede Yogyakarta.

Kata kunci: Literasi Keuangan; UMKM; Kerajinan Perak; Kotagede.
\end{abstract}

\section{*KORESPONDENSI:}

ahmad_maruf@umy.ac.id

\section{ARTIKEL INI TERSEDIA DI:}

http://journal.umy.ac.id/index.php/jerss

DOI: 10.18196/jerss.030101

\section{SITASI:}

Prihatin, J., \& Maruf, A. (2019). Analisis Tingkat Literasi Keuangan pada Pelaku Usaha Mikro Kecil dan Menengah Kerajinan Perak di Kotagede Yogyakarta. Journal of Economics Research and Social Sciences, 3(1), 1-10.

\section{Pendahuluan}

Perkembangan zaman saat ini membuat kebutuhan dan keinginan masyarakat menjadi semakin kompleks. Hal ini yang terkadang mendorong pola hidup konsumtif menjadi hal yang biasa di tengah masyarakat, di mana melakukan pembelian akan hal- hal yang tidak mempertimbangkan dampak kedepanya seolah-olah menjadi hal yang biasa. Kemudahan dalam bertransaksi memberikan dampak positif dan negatif dalam pengelolaan keuangan seseorang. Pengelolaan keuangan ini menjadi salah satu faktor dari kondisi keuangan dari seseorang yang terkadang menyebabkan seseorang berada dalam kondisi kesulitan keuangan. Pengelolaan keuangan ini sangat dipengaruhi oleh literasi keuangan (financial literacy) yang dimiliki oleh seseorang itu sendiri. Literasi keuangan (financial literacy) menjadi salah satu pemahaman yang semakin diperlukan untuk menciptakan penduduk yang berkualitas dan memiliki kecerdasan finansial yang baik, agar tidak hanya memahami secara materi ataupun pemahaman saja, namun juga praktik-praktik agar mampu mengikuti perkembangan pasar keuangan. Literasi keuangan menjadi sebuah kebutuhan dasar yang berupa pengetahuan dan kemampuan untuk mengelola keuangan pribadi agar dapat membuat keputusan yang tepat dalam keuangan sehingga dapat terhindar dari masalah keuangan. 
21,84

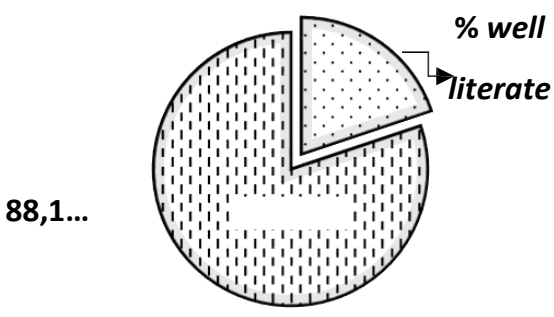

Tahun 2013
$29,66 \%$

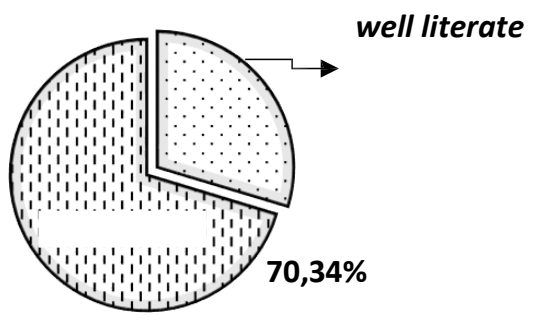

Tahun 2016

Gambar 1 Hasil Survei Tingkat Literasi Keuangan di Indonesia Tahun 2013 dan 2016 Sumber: Survei Nasional Literasi dan Inklusi Keuangan 2016 OJK

Pada gambar 1 menunjukkan hasil survei tingkat literasi keuangan di Indonesia yang dilakukan oleh OJK, pada tahun 2013 tingkat literasi keuangan masyarakat Indonesia hanya 21,84\%. Sedangkan pada tahun 2016 tingkat literasi keuangan masyarakat Indonesia meningkat menjadi 29,66\%. Tingkat literasi keuangan di Indonesia masih kalah dengan beberapa negara di ASEAN. Tingkat literasi keuangan di negara Singapura sudah mencapai 96\%, Malaysia mencapai 81\%, dan Thailand 78\% (Liputan6, 2016).

Sesuai dengan perkembangan zaman yang kini kaya akan teknologi, masyarakat harus memiliki pengetahuan dalam mengelola keuangan. Selain berpengaruh bagi keuangan pribadi, literasi keuangan (financial literacy) ekonomi pribadi individu, literasi keuangan juga berpengaruh terhadap pengelolaan usaha, bisnis, dan UMKM (Usaha Mikro Kecil dan Menengah) yang dikelolanya. Menurut Aribawa (2016), tingkat literasi keuangan yang baik akan menciptakan manajemen keuangan yang baik, hal ini akan meningkatkan kinerja dari usaha, bisnis, dan UMKM tersebut. Menurut Djuwita dan Yusuf (2018), financial behaviour mempengaruhi perkembangan usaha, bisnis dan UMKM.

UMKM juga berpengaruh pada perekonomian daerah-daerah di Indonesia, salah satunya Daerah Istimewa Yogyakarta, menurut kepala BPS D.I.Y, Bapak Priyono, dalam tribun Jogja, industri pengolahan, pertanian, penyediaan akomodasi, dan makanan minuman, konstruksi, dan perdagangan adalah penyumbang terbesar PDRB D.I.Y, kontribusinya mencapainya 53,40\%. Sehingga, keberlangsungan UMKM ini menjadi sangat penting bagi sektor perekonomian.

Berdasarkan uraian dari latar belakang di atas, penulis ingin melakukan penelitian tentang tingkat literasi keuangan (financial literacy) yang harus dimiliki pelaku UMKM kerajinan perak di Kotagede demi mencapai pemahaman tingkat literasi keuangan. 


\section{Tinjauan Pustaka}

Yıldırım, Bayram, Oğuz, dan Günay (2017), dalam penelitiannya tingkat literasi keuangan digolongkan ke dalam dua kategori, yaitu literasi keuangan dasar, dan lanjutan. Ditemukan bahwa tingkat literasi keuangan rata-rata karyawan Kardemir Inc. rata-rata berada di tingkat literasi keuangan dasar, dan tingkat pendidikan dan pendapatan berpengaruh positif dan signifikan, di mana jika penghasilan dan tingkat pendidikan makin tinggi meningkat, maka tingkat literasi keuangan juga akan meningkat. Penelitian yang dilakukan oleh Murugiah (2016) menghasilkan temuan dari beberapa variabel independen yang mempengaruhi tingkat literasi keuangan seseorang, variabel tingkat pendidikan memiliki pengaruh paling tinggi untuk tingkat literasi keuangan, diikuti oleh tingkat pendapatan, usia, dan jenis kelamin. Usia $41-45$ paling tinggi. Sedangkan jenis pekerjaan dan status pernikahan tidak berpengaruh terhadap tingkat literasi keuangan yang dimiliki seseorang.

Ergun (2017), menunjukkan hasil responden laki-laki memiliki tingkat literasi keuangan yang lebih baik dibanding perempuan, dan mahasiswa magister memiliki tingkat literasi keuangan yang paling baik, dan program studi bisnis memiliki tingkat literasi keuangan yang paling tinggi. Mahasiswa yang tidak tinggal dengan keluarga memiliki tingkat literasi keuangan yang lebih baik dibandingkan dengan yang tinggal di asrama kampus atau dengan keluarga, saran teman menjadi pertimbangan yang paling banyak dipilih responden, dan mereka yang pendapatan lebih tinggi memiliki tingkat literasi yang lebih baik, mahasiswa mendapat informasi tentang keuangan dari pendidikan universitas dibandingkan dari televisi, dan media sosial. Mahasiswa yang mengambil kursus atau kelas tambahan mengenai keuangan memiliki tingkat literasi keuangan yang lebih baik dibanding yang tidak.

Hasil penelitian yang dilakukan oleh Mustapha dan Jeyaram (2015), menunjukkan hasil laki-laki memiliki tingkat literasi keuangan yang lebih baik dibandingkan dengan perempuan, dan etnis cina memiliki tingkat literasi keuangan yang paling baik dibandingkan melayu, dan lainya, mahasiswa akuntansi memiliki tingkat literasi keuangan yang paling baik dibanding dengan bisnis, ekonomi.Penelitian yang dilakukan oleh Saeed Karimi dkk (2014), menunjukkan hasil usia, jenis kelamin, status perkawinan, status pekerjaan, pendidikan, dan kemandirian keuangan mempengaruhi tingkat literasi keuangan seseorang, sedangkan pendidikan orang tua tidak berpengaruh terhadap literasi seseorang.

Menurut Mabarire dan Ali (2014), tingkat literasi keuangan karyawan rata-rata berada di tingkat yang rendah, jenis kelamin, usia, tingkat pendidikan, pendapatan tambahan, sumber informasi, dan nasehat keuangan menjadi faktor yang mempengaruhi tingkat literasi keuangan. Dalam penelitian yang dilakukan oleh Yiing-Jia (2017), ia menemukan rata-rata tingkat literasi masyarakat Malaysia berada di tingkat yang baik, dan merencanakan anggaran dalam kehidupan, faktor yang mempengaruhi tingkat literasi keuangan di antaranya, etnis, pendapatan, jenis kelamin, pendapatan, pendidikan, usia, 
dan pengetahuan keuangan memberikan pengaruh yang signifikan terhadap tingkat literasi keuangan seseorang.

\section{Metode Penelitian}

Objek dalam penelitian ini merupakan tingkat literasi keuangan dikalangkan pada pelaku UMKM kerajinan perak di Kotagede, Yogyakarta. Sedangkan untuk subyek dalam penelitian ini adalah pelaku UMKM kerajinan perak di Kotagede Yogyakarta yang terdaftar oleh Dinas Perdagangan, Perindustrian, Koperasi, dan Transmigrasi (prindagkoptan) Kota Yogyakarta pada tahun 2018.

Dalam penelitian ini, data yang digunakan adalah data yang bersifat kuantitatif karena dinyatakan dengan angka-angka yang menunjukkan nilai terhadap besaran atas variabel yang diwakilinya (Sugiyono, 2015). Data yang digunakan dalam penelitian ini adalah data primer Sumber data yang digunakan dalam penelitian ini adalah data primer. Data primer menurut Sugiyono (2015) adalah sumber data yang langsung memberikan data kepada pengumpul data. Data primer dalam penelitian ini diperoleh dari menyebar kuesioner ke pada pelaku UMKM kerajinan perak di Kotagede Yogyakarta.

Menurut Sugiyono (2015), populasi adalah wilayah generalisasi yang terdiri atas obyek atau subyek yang mempunyai kualitas dan karakteristik tertentu yang di tetapkan oleh peneliti untuk dipelajari dan kemudian ditarik kesimpulannya. Populasi dalam penelitian ini adalah pelaku UMKM kerajinan perak yang berada di Kotagede Yogyakarta. Adapun karakteristik responden yang menjadi objek penelitian yaitu pelaku pemilik usaha kerajinan perak yang terdaftar pada Dinas Perindagkoptan (Perindustrian, Perdagangan, Koperasi, dan Pertanian) Kota Yogyakarta pada tahun 2018. Jumlah populasi dalam penelitian ini ialah 113 pemilik, dan arena jumlahnya 113, populasi ini digunakan semua sebagai responden dalam penelitian ini.

Metode pengumpulan data adalah dengan cara memberikan sepaket pertanyaan atau pernyataan tertulis kepada responden untuk dijawab (Sugiyono, 2015). Pengumpulan data dalam penelitian ini menggunakan teknik angket (wawancara). Penelitian ini menggunakan kuesioner sebagai cara dalam pengumpulan data, penelitian ini juga menggunakan skala likert, yaitu skala yang digunakan untuk mengukur sikap, pendapat, atau gejala sosial (Sugiyono, 2015). Angket merupakan metode dengan menyebarkan kuesioner kepada responden untuk diisi dari daftar pernyataan yang telah dibuat oleh peneliti. Kuesioner dalam penelitian ini berisi karakteristik responden, pertanyaan dan pernyataan. Pernyataan dalam kuesioner penelitian ini seluruhnya berjumlah 30 buah. 


\section{Hasil dan Pembahasan}

Dalam penelitian ini, penulis melakukan beberapa pengujian untuk melihat membuktikan apakah data bisa digunakan. Pengujian yang pertama yakni, Uji Validitas. Hasil uji validitas didapat nilai-nilai sebagai berikut, yang ditunjukan pada tabel 1.

Tabel 1 Hasil Uji Validitas

\begin{tabular}{|c|c|c|c|}
\hline Kategori & $\begin{array}{c}\text { Kode } \\
\text { Pertanyaan }\end{array}$ & $\begin{array}{c}\text { Pearson } \\
\text { Correlation }\end{array}$ & Keterangan \\
\hline \multirow[t]{11}{*}{ Pengetahuan dasar keuangan } & S1 & 0,527 & Valid \\
\hline & S2 & 0,359 & Valid \\
\hline & S3 & 0,433 & Valid \\
\hline & S4 & 0,516 & Valid \\
\hline & S5 & 0,59 & Valid \\
\hline & S6 & 0,386 & Valid \\
\hline & S7 & 0,47 & Valid \\
\hline & S8 & 0,522 & Valid \\
\hline & S9 & 0,532 & Valid \\
\hline & S10 & 0,43 & Valid \\
\hline & S11 & 0,539 & Valid \\
\hline \multirow[t]{7}{*}{ Menabung dan Meminjam } & S12 & 0,448 & Valid \\
\hline & S13 & 0,647 & Valid \\
\hline & S14 & 0,69 & Valid \\
\hline & S15 & 0,647 & Valid \\
\hline & S16 & 0,69 & Valid \\
\hline & S17 & 0,376 & Valid \\
\hline & S18 & 0,465 & Valid \\
\hline \multirow[t]{6}{*}{ Investasi } & S19 & 0,535 & Valid \\
\hline & S20 & 0,503 & Valid \\
\hline & S21 & 0,688 & Valid \\
\hline & S22 & 0,695 & Valid \\
\hline & S23 & 0,688 & Valid \\
\hline & S24 & 0,695 & Valid \\
\hline \multirow[t]{6}{*}{ Asuransi } & S25 & 0,909 & Valid \\
\hline & S26 & 0,511 & Valid \\
\hline & S27 & 0,321 & Valid \\
\hline & S28 & 0,44 & Valid \\
\hline & S29 & 0,895 & Valid \\
\hline & S30 & 0,909 & Valid \\
\hline
\end{tabular}

Sumber: Data Primer Diolah

Berdasarkan hasil Uji Validitas yang ditunjukkan pada tabel 1, hasilnya menunjukkan bahwa seluruh nilai Pearson Correlation pada pertanyaan yang diajukan lebih besar dari nilai $r$-tabel dengan signifikan 0,05 yang nilainya 0,1848 , dengan demikian pernyataan pada asuransi, semua nomor dianggap valid, sebab nilai Pearson Correlation > 0,1848.

Uji selanjutnya yakni Uji Reliabilitas, berikul hasil uji reliabilitas yang telah didapatkan. 
Analisis Tingkat Literasi Keuangan pada Pelaku Usaha Mikro Kecil dan Menengah ...

Tabel 2 Uji Reliabilitas

\begin{tabular}{|c|c|c|}
\hline Kategori & $\begin{array}{c}\text { Nilai Cronbanch's } \\
\text { alpha }\end{array}$ & Keterangan \\
\hline Pengetahuan Dasar Keuangan & 0,651 & Reliabel \\
\hline Menabung dan Meminjam & 0,652 & Reliabel \\
\hline Investasi & 0,702 & Reliabel \\
\hline Asuransi & 0,772 & Reliabel \\
\hline
\end{tabular}

Sumber: Data diolah

Berdasarkan hasil uji reliabilitas yang ditunjukkan pada tabel 2, diketahui nilai cronbach alpha dari setiap variabel lebih dari 0,60, dengan demikian seluruh bagian variabel $Y$ dikatakan reliabel, karena nilai cronbach alpha. $>0,6$.

Dalam penelitian ini, hasil uji reliabilitas didapat nilai-nilai sebagai berikut, yang ditunjukan pada tabel 3.

Tabel 3 Uji Asumsi Klasik

\begin{tabular}{|c|c|c|c|c|c|}
\hline \multirow[t]{2}{*}{ Variabel } & \multirow{2}{*}{$\begin{array}{l}\text { Normalitas } \\
\text { Signifikansi }\end{array}$} & \multicolumn{2}{|c|}{ Multikolinieritas } & \multirow{2}{*}{$\begin{array}{l}\text { Heteroskedastisitas } \\
\text { Sig. }\end{array}$} & \multirow{2}{*}{$\begin{array}{l}\text { Autokorelasi } \\
\text { DW }\end{array}$} \\
\hline & & $\begin{array}{c}\text { tolerance } \\
\text { value }\end{array}$ & VIF & & \\
\hline Jenis kelamin & \multirow[t]{5}{*}{0,234} & 0,775 & 1,29 & 0,18 & \multirow[t]{5}{*}{1,863} \\
\hline Usia & & 0,224 & 4,454 & 0,111 & \\
\hline Pendidikan terakhir & & 0,406 & 2,462 & 0,091 & \\
\hline Lama usaha & & 0,23 & 4,341 & 0,65 & \\
\hline Omzet penjualan & & 0,578 & 1,729 & 0,114 & \\
\hline
\end{tabular}

Sumber: Data diolah

Berdasarkan hasil uji asumsi klasik yang ditunjukkan pada tabel 3, diketahui bahwa seluruh data yang digunakan dalam penelitian ini lolos uji asumsi klasik. Setelah semua Uji Asumsi Klasik dilakukan, pengujian hipotesis perlu dilakukan untuk melihat pengaruh masing-masing variabel.

Tabel 4 Tingkat Literasi Keuangan

\begin{tabular}{llcc}
\hline Kategori & Jumlah nilai $X$ & $\begin{array}{c}\text { Frekuensi } \\
\text { (Orang) }\end{array}$ & $\begin{array}{c}\text { Persentase } \\
(\%)\end{array}$ \\
\hline Tinggi & $X>84$ & 11 & 9,7 \\
Sedang & $68 \leq X \leq 84$ & 97 & 85,8 \\
Rendah & $X<68$ & 5 & 4,5 \\
\hline
\end{tabular}

Sumber: Data dioleh

Tingkat literasi keuangan pelaku UMKM kerajinan perak di Kotagede Yogyakarta, ratarata berada pada kriteria sedang. Dalam penelitian ini hasil $f$, menunjukan variabel bebas dalam penelitian yang berpengaruh terhadap variabel terikat secara simultan terhadap tingkat literasi keuangan pelaku usaha mikro kecil dan menengah kerajinan perak di Kotagede, Yogyakarta ditunjukan pada tabel 5. 
Analisis Tingkat Literasi Keuangan pada Pelaku Usaha Mikro Kecil dan Menengah ...

Tabel 5 Hasil Uji F

\begin{tabular}{llcrc}
\hline Model & \multicolumn{1}{c}{ Variabel } & F-hitung & F-tabel & Hasil \\
\hline$X_{1} Y$ & Jenis kelamin & 20,455 & 2,30 & Diterima \\
$X_{2} Y$ & Usia & & & \\
$X_{3} Y$ & Tingkat Pendidikan terakhir & & & \\
$X_{4} Y$ & Lama usaha & & & \\
$X_{5} Y$ & Omzet penjualan & & & \\
\hline
\end{tabular}

Sumber: Data diolah

Tabel 5 menunjukan bahwa variabel bebas dalam penelitian ini berpengaruh secara simultan terhadap tingkat literaasi keuangan pelaku usaha mikro kecil dan menengah kerajinan perak di Kotagede, Yogyakarta. Dalam penelitian ini, hasil t-tabel menunjukan bahwa variabel bebas dalam penelitian ini berpengaruh terhadap variabel tingkat literasi keuangan pelaku usaha mikro kecil dan menengah kerajinan perak di Kotagede, Yogyakarta.

Tabel 6 Hasil Uji t

\begin{tabular}{cllcc|}
\hline \multicolumn{1}{c}{ Variabel } & $t$ & Sig. & Hasil \\
\hline $\mathrm{X}_{1} \mathrm{Y}$ & Jenis kelamin & 1.332 & 0,186 & Ditolak \\
$\mathrm{X}_{2} \mathrm{Y}$ & Usia & 2.836 & 0,005 & Diterima \\
$\mathrm{X}_{3} \mathrm{Y}$ & Tingkat Pendidikan terakhir & 6.828 & 0,000 & Diterima \\
$\mathrm{X}_{4} \mathrm{Y}$ & Lama usaha & 2.427 & 0,017 & Diterima \\
$\mathrm{X}_{5} \mathrm{Y}$ & Omzet penjualan & 2.990 & 0,003 & Diterima \\
\hline
\end{tabular}

Sumber: Data diolah

Berdasarkan hasil uji di atas, nilai t-hitung lebih besar dari t-tabel adalah 0,05/ 2; 113 $5-1$, dan hasil yang didapat adalah 0,025; 107, maka nilai t-tabel adalah 1,982, dan melihat nilai sig $<0,05$, maka dapat disimpulkan bahwa variabel-variabel bebas yang berpengaruh secara signifikan terhadap variabel bebas adalah: usia, tingkat pendidikan terakhir, lama usaha, omzet penjualan, sedangkan variabel jenis kelamin tidak berpengaruh signifikan.

Berdasarkan analisis statistik deskriptif pada penelitian ini, ditemukan jumlah responden dengan tingkat literasi keuangan kategori sedang sebesar $84,8 \%$ dari total responden, kemudian $9,7 \%$ dari total responden berada pada kategori tinggi, dan untuk kategori rendah 4,5\% dari total responden. Dengan hasil tersebut menunjukkan bahwa rata-rata tingkat literasi keuangan pada pelaku UMKM Kerajinan perak di Kotagede Yogyakarta berada pada tingkat sedang.

Berdasarkan hasil uji hipotesis dengan menggunakan metode uji $\mathrm{t}$, hasilnya dapat menjelaskan bahwa jenis kelamin pelaku UMKM pada industri perak tidak berpengaruh terhadap tingkat literasi keuangan. Sesuai dengan penelitian yang dilakukan oleh Bonita dan Stiawina (2018), Suryani dan Ramadhan (2017), dan Yıldırım dkk. (2017), 
mereka menemukan variabel jenis kelamin tidak berpengaruh terhadap tingkat literasi keuangan seseorang.

Dengan nilai t-hitung sebesar 2,836 dan 1,982 untuk t-tabel, hasil tersebut menunjukkan bahwa t-hitung > t-tabel. Hal tersebut menunjukkan bahwa dengan tingkat signifikansi 5 persen, terdapat perbedaan tingkat literasi keuangan pada pelaku UMKM industri perak di Kotagede Yogyakarta berdasarkan usia. Hasil yang sesuai juga ditemukan oleh Karimi dkk. (2014), dalam penelitian tersebut, mereka menemukan bahwa usia berpengaruh terhadap tingkat literasi keuangan pada pelajar di Irlandia. Yıldırım dkk. (2017) dan Mabarire dan Ali (2014), juga menunjukkan hasil yang signifikan dari variabel usia terhadap tingkat literasi keuangan. Margaretha dan Sari (2015), usia mempunyai korelasi langsung terhadap literasi keuangan, semakin bertambah usia maka semakin banyak informasi yang diperoleh terkait dengan masalah keuangan. Maka, semakin bertambah dewasa maka literasi keuangan seseorang akan semakin meningkat seiring.

Untuk variabel pendidikan terakhir, hasil uji t menunjukkan nilai t-hitung sebesar 6,828, dan untuk nilai t-tabel adalah 1,982, dalam kata lain nilai t-hitung > t-tabel. Sehingga, dapat disimpulkan bahwa dengan signifikansi 5 persen, terdapat perbedaan tingkat literasi keuangan pada pelaku UMKM kerajinan perak di Kotagede Yogyakarta berdasarkan tingkat pendidikan terakhir. Hasil tersebut sejalan dengan penelitian oleh Lantara dan Kartini (2015), Dewanty dan Isbahah (2018), Yiing-Jia (2017), Kutlu (2017), dan Margaretha dan Sari (2015), dan Murugiah (2016), di mana mereka mengatakan bahwa tingkat pendidikan berbanding lurus dengan tingkat literasi keuangan. Selain keempat penelitian tersebut, dalam penelitian yang dilakukan oleh menunjukkan hasil yang sama.

Perbedaan tingkat literasi keuangan dari lama usaha dilihat dengan menggunakan uji t, hasil yang didapat menunjukkan nilai t-hitung sebesar 2,427, dengan nilai t-tabel sebesar 1,982, dalam kata lain nilai t-hitung > t-tabel, yang artinya dengan tingkat signifikansi 5 persen, variabel lama usaha berpengaruh terhadap tingkat literasi keuangan. Temuan yang sama juga di dapat Bonita dan Stiawina (2018), penelitian tersebut menyatakan bahwa variabel lama usaha berpengaruh signifikan terhadap tingkat literasi keuangan yang menjadi variabel terikat. lamanya waktu usaha yang variatif ini tentu menggambarkan bahwa masing-masing pedagang telah memiliki pengalaman usaha yang berbeda-beda pula. Pengalaman usaha yang dimiliki pedagang termasuk di dalamnya adalah dalam bidang keuangan tentu akan mempengaruhi terciptanya pertumbuhan suatu usaha.

Variabel yang tidak kalah pentingnya yakni omzet penjualan per-bulan, dengan nilainya t-hitung sebear 2,990, nilai t-tabel sebesar 1,98238 dan tingkat signifikansi 1 persen, dapat disimpulkan bahwa omzet pernjualan per-bulan berpengaruh signifikan terhadap tingkat literasi keuangan. Suryani dan Ramadhan, (2017) menunjukkan hasil yang signifikan pada variabel pendapatan terhadap tingkat literasi keuangan. Temuan yang sama dalam penelitian yang dilakukan oleh Lantara dan Kartini (2015), Dewanty dan 
Isbahah (2018), dan Yiing-Jia (2017), dalam ketiga penelitian tersebut, ditemukan hasil pengaruh signifikan dari variabel omzet penjualan per-bulan terhadap tingkat literasi keuangan. Menurut Margaretha dan Sari (2015), tingkat pendapatan bulanan berpengaruh terhadap literasi keuangan. Maka semakin tinggi pendapatan seseorang maka tingkat literasi keuangannya juga akan meningkat.

\section{Kesimpulan}

Setelah melakukan beberapa Langkah pengujian terhadap model, penulis mendapatkan hasil yang sesuai dengan hipotesis penelitian ini. Berdasarkan hasil analisis data yang telah dilakukan, dapat disimpulkan bahwa, usia, tingkat Pendidikan, lama usaha, serta pendapatan per-bulan mempengaruhi tingkat literasi keuangan pada pelaku UMKM kerajinan perak di Kotagede, Yogyakarta. Sedangkan jenis kelamin pelaku usaha tidak memiliki pengaruh terhadap tingkat literasi pelaku UMKM, atau dalam kata lain wanita dan laki-laki memiliki tingkat literasi yang sama tanpa memandang jenis kelamin mereka.

\section{Daftar Pustaka}

Aribawa. D. (2016). Pengaruh Literasi Keuangan terhadap Kinerja dan Keberlangsungan UMKM di Jawa Tengah. Jurnal Siasat Bisnis. 20(1), 1-13. https://doi.org/10.20885/jsb.vol20.iss1.art1

Bonita, A. P. A \& Stiawina, N. D. (2018). Analisis Determinan Tingkat Literasi Keuangan Pedagang Pada Pasar Tradisional di Kota Denpasar. E-Jurnal EP Unud. 7(2), 354380. Diakses dari https://ojs.unud.ac.id/index.php/eep/article/view/37690

Dewanty, N. \& Isbanah, Y. (2018). Determinants of the Financial Literacy: Case Study on Career Woman in Indonesia. Etikonomi. 17(2), 285 - 296. http://dx.doi.org/10.15408/etk.v17i2.6681

Djuwita, D. \& Yusuf, A. A. (2018). Tingkat Literasi Keuangan Syariah di Kalangan UMKM dan Dampaknya Terhadap Perkembangan Usaha. Al-Amwal. 10(1), 105-127. http://dx.doi.org/10.24235/amwal.v10i1.2837

Ergun, K. (2017). Financial Literacy Among University Students: A Study in Eight European Countries. International Journal of Consumer Studies, 4(2), 2-15. https://doi.org/10.1111/ijcs.12408

Lantara, I W. N. \& Kartini, N. K. R. (2015). Financial Literacy Among University Students: Empirical Evidence from Indonesia. Journal of Indonesian Economy and Business. 30(3), 247-256. https://doi.org/10.22146/jieb.10314

Mabarire, T. T. \& Ali, A. I. (2014). Determinants of Financial Literacy Levels among Employees of Kenya Ports Authority in Kenya. Research Journal of Finance and Accounting. 5(16), 44-52. Diakses dari https://iiste.org/Journals/index.php/RJFA/article/view/14813

Margaretha, F. \& Sari, S. M. (2015). Faktor Penentu Tingkat Literasi Keuangan pada Pengguna Kartu Kredit di Indonesia. Jurnal Akutansi \& Investasi. 16(2), 132-144. Diakses dari https://journal.umy.ac.id/index.php/ai/article/view/1354 
Murugiah, L. (2016). The Level of Understanding and Strategies to Enhance Financial Literacy among Malaysian. International Journal of Economics and Financial Issues, 6(3), 130-139. Diakses dari https://www.econjournals.com/index.php/ijefi/article/view/2621

Mustapha, M., \& Jeyaram, S. (2015). Financial Literacy and Demographic Factors.Journal of Technology Management and Business, 2(1), 1-8. Diakses dari https://publisher.uthm.edu.my/ojs/index.php/jtmb/article/view/1091

Suryani, S. \& Ramadhan, S. (2017). Analisis Literasi Keuangan Pada Pelaku Usaha Mikro di Kota Pekanbaru. Journal of Economic, Business and Accounting (COSTING). 1(1), 12-22. https://doi.org/10.31539/costing.v1i1.67

Yiing-Jia, L. (2017). The Influence of Socio-Demographic and Financial Knowleadge Factors on Financial Management Practices of Malaysians. International Journal of Business and Society, 18(1), 33-50. Diakses dari http://www.ijbs.unimas.my/images/repository/pdf/Vol18-no1-paper3.pdf

Yıldırım, M., Bayram, F., Oğuz, A., \& Günay, G. (2017). Financial Literacy Level of Individuals and Its Relationships to Demographic Variables. Mediterranean Journal of Social Sciences MCSER Publishing, Rome-Italy. 8(3), 19-26. Diakses dari http://archive.sciendo.com/MJSS/mjss.2017.8.issue3/mjss.2017.v8n3p19/mjss.2017.v8n3p19.pdf 